\title{
Optimization of Performance Measures FOR THE IMPROVEMENT OF LEAN MANUFACTURING SYSTEM
}

\author{
S.R. MAHENDRAKAR
}

Abstract: Lean Manufacturing System works in every area of the value stream by reducing waste in order to reduce lead time, minimizing cost, optimal arrangement of activities, and remain competitive in a rising global market. This research attentions the implementation of lean philosophy in brake lining company with focuses on arrangement of resources. In the present work the use of Lean Manufacturing is to generate strategies to eliminate waste on the shop floor. The Lean Manufacturing tools such as Kaizen were employed to decrease the waste. This paper describes a case study considering changeover time as a performance measures to improve the flow of production by arranging the operations activities. Finally the results obtained show the improvement in the shop floor region.

Key words: Lean Manufacturing, Kaizen, Waste, Changeover time
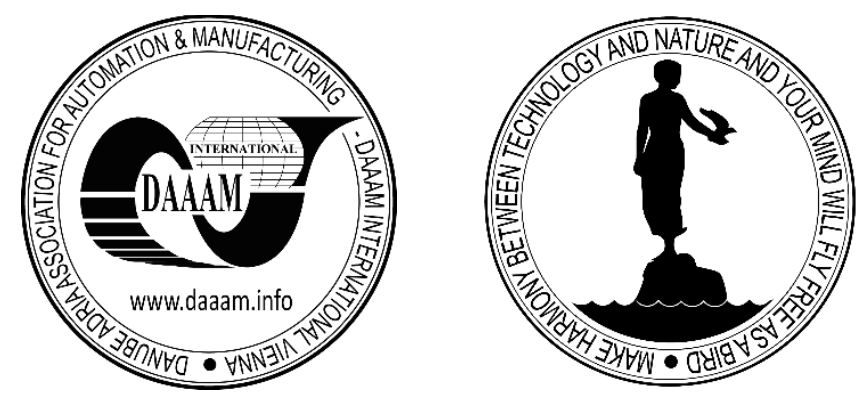

Authors' data: Asst. Prof. Mahendrakar, S[harmila] R[ao], Mechanical Engineering Department, Chandigarh College of Engineering and Technology, Chandigarh, India, msharmila1206@gmail.com

This Publication has to be referred as: Mahendrakar, S[harmila] (2018). Optimization of Performance Measures for the Improvement of Lean Manufacturing System, Chapter 14 in DAAAM International Scientific Book 2018, pp.151-158, B. Katalinic (Ed.), Published by DAAAM International, ISBN 978-3-902734-19-8, ISSN 1726-9687, Vienna, Austria

DOI: $10.2507 /$ daaam.scibook.2018.14 


\section{Introduction}

To be competitive and profitable, the industry has to be quick to respond to the rapidly changing world in which, emerging economies, new concepts and philosophies of doing business, technical developments and ever changing needs of customers pose serious challenges to its survival.

Because of this the manufacturing systems have been drastically changing over the period of time, which is a continuous process [7, 12].Lean manufacturing system (LMS) is a philosophy that aims to improve productivity and reduce waste. Lean manufacturing focuses less floor space, optimal utilization of time, less use of equipment and tools and less workers in completing an order [10, 17, 18]. Examples of waste minimization consist of the reduction of process and product defects, less scrap, and low inventory [4].

Vinodh et al. [16] suggests that the objective of lean manufacturing is to reduce waste in terms of work-in-process (WIP) inventory time in transferring the material and setup time [3]. Waste can be defined in another way that does not contribute value to the product, for which the customer is unwilling to pay. Some of the wastes are overproduction, WIP inventory, finished parts inventory, transportation, defects, and scrap [8].The implementation of lean manufacturing concept in the different sectors has been recorded in the literature in recent years. The analysis of case studies dealing with the application of lean manufacturing can be found in steel production [1], aerospace manufacturing [2].

Pattnaik et al. [11] combined the concept of lean manufacturing with cellular manufacturing to improve the efficiency of ammunition components manufacturing. The present work was conducted at SBL Limited, India, engaged in manufacturing brake linings.

The main aim of present work is to (1) present an overview of LMS; (2) state the relevant information about the manufacturing processes; and (3) implement a lean manufacturing system to improve productivity of brake lining manufacturing at SBL Limited.

\section{Lean manufacturing tools}

A manufacturing system which is defined as a collection of integrated equipment and human resources, the basic function of which is to execute one or more processing and/or assembly tasks on a starting raw material, part or set of parts.

Lean manufacturing suggests many tools, which can assist in making the value to a customer in a simpler way. Some of the most broadly used tools are total productive maintenance (TPM), value stream mapping (VSM), JIT, 5S, and Kaizen [5]. 


\subsection{Total productive maintenance}

TPM is a management philosophy that focuses on connecting all employees in a manufacturing organization in equipment improvement. It consists of different methods, which are known from maintenance management experience to be effective in improving reliability, quality, maintainability and production.

\subsubsection{Total productive maintenance}

Value stream mapping is also known as VSM. It is one of the most successful tools of lean manufacturing. VSM mainly focuses the stream of the value and seeks to find the areas of improvement [6].

VSM focuses on value in the framework of what the customer is willing to pay not for the wastes generated by the organization [14]. The main objective of VSM is to find the lead-time associated with a certain product flow throughout a system [15]. The whole process of VSM can be divided into four key steps: (1)identify the family of products, (2) generate a current state value stream map, (3) suggests a future state value stream map, and (4)create an action plan.

\subsubsection{Just in time}

The aim of JIT is to keep the level of inventory to a smallest amount. This is achieved by permitting each operation to pull the objects from the precedential operation rather than pushing objects in the production system.

\subsection{4 $5 S$}

$5 \mathrm{~S}$ is another useful tool of lean manufacturing, extensively used to maintain the working area neat, clean, and safe. The name $5 \mathrm{~S}$ generates from the first letter in the five Japanese words: Seiri, Seiton, Seison, Seiketsu, and Shitsuke. The Japanese words' meanings in English are sort, straighten, shine, standardize, and sustain. Usually, 5S is implemented in bit by bit manner.

In nutshell, all the objects lying at the work centre are differentiated as necessary and unnecessary objects. Thus, all this unnecessary objects are removed in a sorting phase. In the next phase, all the necessary items are arranged, and their position is defined. In a shine phase, the every area of the workplace is neatly cleaned, and the sources of contamination are identified. In the standardize phase, method is defined to maintain the improvement. In the sustain phase, the comprehensive program is developed to train people for good work practice.

\subsubsection{Kaizen}

Kaizen is one of the most popular terms used in the field of lean manufacturing. Kaizen means constant improvement. The surroundings is created at the work centre that enthusiasts people engaged in the day-to-day work to make the method of work more productive or better by continuously improving it. 


\section{Manufacturing processes}

The first step in manufacturing of Brake linings is the identification of backing plate which depends upon the application of it. Next is the machining process to make it clean and get accurate size.

Because the brake lining is open to atmosphere and often in touch with corrosive materials so rust prevention material is coated over it. Next is the adhesive material is put over it to join with friction material. Friction materials are composed of a relatively soft but tough and heat-resistant material with a high coefficient of dynamic friction. Friction material is mounted to a solid metal backing using high-temperature adhesives.

The complete assembly (including lining and backing plate) is then clamping and baking in an oven. Then they are grinding to make it in final shape and size. Finally they are checked by gauges before packaging and shipping to the customer. Figure 1 shows the process flow chart of brake lining manufacturing.

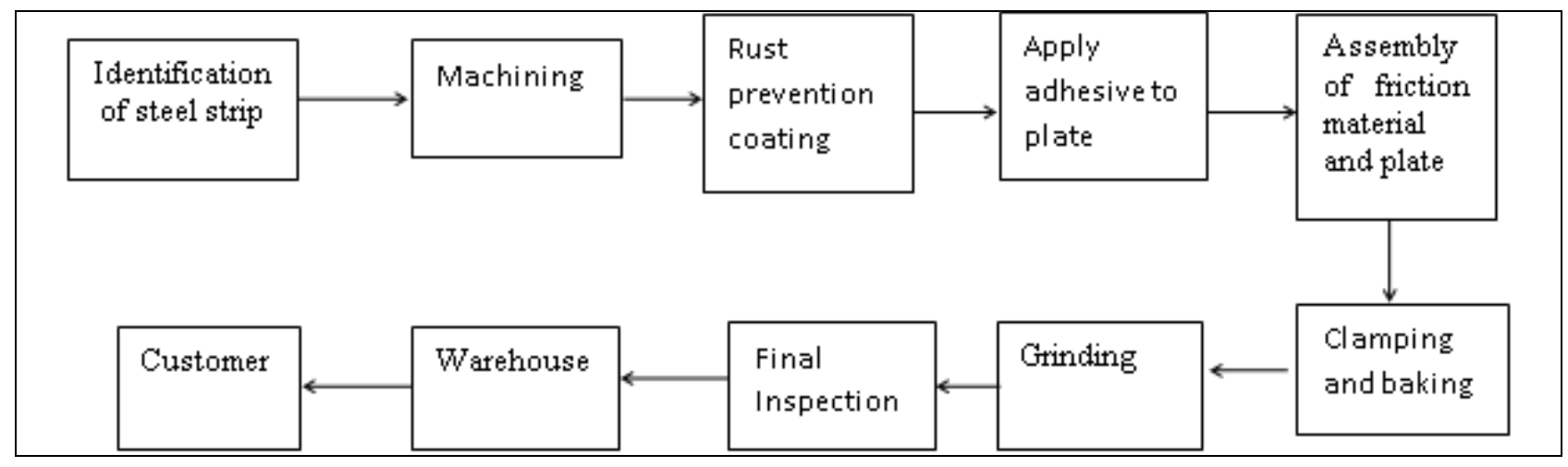

Fig. 1. Flow chart of brake lining manufacturing

\section{Changeover time}

Changeover time is the time taken in changing one activity to another activity[17, 18]. The time includes adding and removing the items.

For assembly of friction material and plate different activities are required and to complete the assembly various tools (Items) are needed (Figure1). These items are the direct or indirect parts of a machine. In the present case only direct parts are considered. Table 1 gives different activities and their items(assumed).

\begin{tabular}{|l|l|}
\hline Activities & Items $(\mathrm{I})$ \\
\hline $\mathrm{a}_{11}$ & $(\mathrm{c}, \mathrm{d}, \mathrm{e})$ \\
\hline $\mathrm{a}_{12}$ & $(\mathrm{e}, \mathrm{g}, \mathrm{h})$ \\
\hline $\mathrm{a}_{13}$ & $(\mathrm{c}, \mathrm{d}, \mathrm{g}, \mathrm{f})$ \\
\hline
\end{tabular}

Tab. 1. Activities and its Items 
Table 2 gives the Changeover time in adding the Items from one activity to another.

\begin{tabular}{|l|l|l|l|l|l|l|}
\hline Items $\backslash$ Changeover time & $\mathrm{a} 112$ & $\mathrm{a} 123$ & $\mathrm{a} 131$ & $\mathrm{a} 121$ & $\mathrm{a} 132$ & $\mathrm{a} 113$ \\
\hline $\mathrm{c}$ & - & 1 & - & 1 & - & - \\
\hline $\mathrm{d}$ & - & 3 & - & 1 & - & - \\
\hline $\mathrm{e}$ & - & - & 4 & & 2 & - \\
\hline $\mathrm{f}$ & - & 4 & - & - & - & 4 \\
\hline $\mathrm{g}$ & 6 & - & - & - & - & 4 \\
\hline $\mathrm{h}$ & 6 & - & - & - & 6 & - \\
\hline
\end{tabular}

Tab. 2. ChangeoverTime (Sec) when adding the Items

$$
\mathrm{NCAT}=\alpha \mathrm{mcij}+\beta \mathrm{mcpq}
$$

$\alpha \& \beta$ are the weights assigned $(\alpha+\beta=1)$ and $i, j, p$ and $q=1,2,3$ and the assumed value of $\alpha \& \beta$ are 0.5. E.g. for Item c, NCATc $=\alpha$ mc $23+\beta$ mc $21=(1+1) / 2=1$.

Similarly, normalized changeover addition time for different items can be calculated and listed in Table 4. Table 3 gives the Changeover time in removing the items from one activity to another.

\begin{tabular}{|l|l|l|l|l|l|l|}
\hline Items $\backslash$ changeover time & $\mathrm{a} 112$ & $\mathrm{a} 123$ & $\mathrm{a} 131$ & $\mathrm{a} 121$ & $\mathrm{a} 132$ & $\mathrm{a} 113$ \\
\hline $\mathrm{C}$ & .5 & - & - & - & .5 & - \\
\hline $\mathrm{D}$ & 1 & - & - & - & 1 & - \\
\hline E & - & 2 & - & - & - & 1 \\
\hline F & - & - & 1 & - & 3 & - \\
\hline G & - & - & 2 & 3 & - & - \\
\hline H & - & 4 & - & 2 & - & - \\
\hline
\end{tabular}

Tab. 3. Changeover Time (Sec) when removing the Items

The Normalized Changeover removal time (NCRT) for different Items is given by

$$
\mathrm{NCRT}=\boldsymbol{\sigma} \mathrm{mcij}+\Omega \mathrm{mcpq}
$$

where $\sigma \& \Omega$ are the weights assigned $(\sigma+\Omega=1)$ and $\mathrm{i}, \mathrm{j}, \mathrm{p}$ and $\mathrm{q}=1,2,3$ and the assumed value of $\boldsymbol{\sigma} \& \Omega$ are 0.5 . E.g. for Item c, NCRTc $=\boldsymbol{\sigma} \mathrm{mc} 12+\Omega \operatorname{mc} 32=0.5$.

Similarly Normalized Changeover removal time for different items can be calculated and listed in Table 4.

Table 4 gives the normalized value of Changeover time in adding and removing the Items from one activity to another. 
Mahendrakar, S.: Optimization of Performance Measures for the Improvement of L...

\begin{tabular}{|l|ll|}
\hline Items & $\begin{array}{l}\text { Changeover time } \\
\text { adding the Items }\end{array}$ & $\begin{array}{c}\text { whenChangeover time when removing the } \\
\text { Items }\end{array}$ \\
\hline C & 1 & 0.5 \\
\hline D & 2 & 1 \\
\hline E & 3 & 1.5 \\
\hline F & 4 & 2 \\
\hline G & 5 & 2.5 \\
\hline H & 6 & 3 \\
\hline
\end{tabular}

Tab. 4. Changeovertime (Sec) for different Items (Normalized Value)

Total Changeover Time can be calculated as follows

$$
\text { TCT }(\text { Total ChangeoverTime })_{\mathrm{ij}}=\left(\mu \frac{\text { timeinaddingtheltems }}{\text { Totalavailabletime }}+\Omega \frac{\text { timeinremovingtheltems }}{\text { Totalavailabletime }}\right)
$$

where $\mathrm{i}, \mathrm{j}=1,2,3$ and the assumed value of different weights are $\mu=.6, \Omega=.4$, and Total available time $=20 \mathrm{sec}$. The Items added are $\mathrm{g}$ and $\mathrm{h}$ and the Items removed are $\mathrm{c}$ and $\mathrm{d}$ in changing activity 1 to 2 .

Hence Total Changeover Time $($ TCT12 $)=0.5(5+6) / 20+0.4(1.5) / 20=.4$. Similarly Total Changeover Time for TCT13, TCT23, TCT32, TCT31 and TCT21 can be calculated and listed in table 5.

\begin{tabular}{|l|l|l|}
\hline S.No. & Total Changeover time & Results \\
\hline 1 & TCT $_{12}$ & 0.40 \\
\hline 2 & TCT $_{13}$ & 0.32 \\
\hline 3 & TCT $_{23}$ & 0.43 \\
\hline 4 & TCT $_{32}$ & 0.40 \\
\hline 5 & TCT $_{31}$ & 0.28 \\
\hline 6 & TCT $_{21}$ & 0.40 \\
\hline
\end{tabular}

Tab. 5. Total Changeover Time

The Cumulative Changeover-time for different activities are listed in Table 6.

\begin{tabular}{|l|l|l|l|l|}
\hline S.N. & $\begin{array}{l}\text { Sequence of } \\
\text { activities }\end{array}$ & $\begin{array}{l}\text { Total } \\
\text { Changeover } \\
\text { Time1 }\end{array}$ & $\begin{array}{l}\text { Total } \\
\text { Changeover } \\
\text { Time2 }\end{array}$ & $\begin{array}{l}\text { Cumulative Changeover } \\
\text { Time }\end{array}$ \\
\hline 1 & $\mathrm{a}_{123}$ & 0.40 & 0.43 & 0.83 \\
\hline 2 & $\mathrm{a}_{132}$ & 0.32 & 0.40 & 0.72 \\
\hline 3 & $\mathrm{a}_{213}$ & 0.40 & 0.32 & 0.72 \\
\hline 4 & $\mathrm{a}_{231}$ & 0.43 & 0.28 & 0.71 \\
\hline 5 & $\mathrm{a}_{312}$ & 0.28 & 0.40 & 0.68 \\
\hline 6 & $\mathrm{a}_{321}$ & 0.40 & 0.40 & 0.80 \\
\hline
\end{tabular}

Tab. 6. Cumulative Changeover Time 
It has been found $\mathrm{a}_{312}$ is an optimum sequence of operations activity and will minimize the waste in terms of changeover time.

\section{Conclusions}

The in-tangible benefits obtained after implementation of lean tools are improved teamwork and communication, better flexibility and visibility improves safety, improves morale of the workers. Operator training in skill development would improve competence and thus reduce worker setup and processing time for the machines/processes used in brake lining manufacturing. The performance measures of the Lean manufacturing system give an indication to choose the activities in each stage.

In the present study the performance parameter changeover time has been discussed. This performance parameter is helpful in minimizing the wastes by optimizing the sequence of operations activity. By minimizing the changeover time the lead time can be reduced and the system becomes more responsive. In future the authors plan to develop more performance parameter to the manufacturing system. The lean manufacturing concepts can be extended to other manufacturing areas of the plant such as grinding and machining shop. The results can also be shared with other plants.

\section{References}

Liker, J.K.(1998). Becoming lean. Productivity Press, Portland.

McDonald, T.; Van Aken, E.M.\& Rentes, A.F. (2002). Utilizing simulation to enhance value stream mapping: a manufacturing case application.Int $\mathrm{J}$ Logistics-res Appl,Vol.5,No.2,pp. 213-232.

Micieta, B.; Zavodska, L.; Rakyta, M. \& Binasova, V.(2015).Sustainable Concept for Green Logistics andEnergy Efficiency in Manufacturing, DAAAM International Scientific Book 2015,ISBN 978-3-902734-05-1, ISSN 1726-9687, Vienna, Austria, pp.391- 400.

Mittal,K.K.\& Verma, V. (2016). Lean manufacturing system for air cleaner assembly cell. Int. J. LogisticsSystems and Management, Vol.23,No.3,pp. 314-328.

Mittal, K.K.; Jain, P.K. \& Kumar, D. (2017). Configuration selection in Reconfigurable Manufacturing System based on Reconfigurability. International Journal of Logistics Systems and Management, Vol. 27, No. 3, pp. 363-379.

Monden, Y. (1998). Toyota production system: an integrated approach to just-in-time. 3rd edn. Engineering and Management Press, Norcross.

Mulc, T.; Udiljak, T. \& Ciglar, D. (2015). Structure of Reconfigurable Manufacturing Systems, DAAAM International Scientific Book 2015, ISBN 978-3-902734-05-1, ISSN 1726-9687, Vienna, Austria, pp.369- 390.

Nickels, W.G.;McHingh, J.H.; McHugh, S.M.; Berman, P.D.\& Cossa, R. (2008). Understanding of Canadian business. 4th edn. McGraw Hill, Toronto. 
Pattanaik, L.N.\& Sharma, B.P. (2009). Implementing lean manufacturing with cellular layout. Int J Adv Manuf Technol,Vol.42,pp. 772-779.

Puik, E.; Telgen, D.; Moergestel, L. \& Ceglarek, D. (2017). Assessment of reconfiguration schemes for Reconfigurable Manufacturing Systems based on resources and lead time. Robotics and Computer-Integrated Manufacturing, Vol. 43, pp. 30-38.

Rakyta, M.; Fusko, M.; Haluska, M. \& Grznar, P. (2016). Maintenance Support System for Reconfigurable Manufacturing Systems, Proceedings of the 26th DAAAM International Symposium, ISBN 978-3-902734-07-5, ISSN 1726-9679, Vienna, Austria pp.1102-1108.

Ramesh, V.; Sreenivasa Prasad,K.V.\& Srinivas, T.R. (2011). Implementation of a lean model forcarrying out value stream mapping in a manufacturing industry. J Ind Syst Eng,Vol.2,No.3,pp. 180-196.

Singh, B.; Garg, S.K.\& Sharma, S.K. (2011). Value stream mapping: literature review and implication for Indian industry. Int J Adv Manuf Technol,Vol.53,pp. 799-809. Vinodh, S.; Arvind, K.R. \& Somanaathan, M. (2011). Tools and techniques for enabling sustainability through lean initiatives. Clean Techn Environ Policy,Vol.13,pp. 469-479.

Womack, J.P. \& Jones, D.T. (1996). Lean thinking. Simon and Schuster, New York. Womack, J.P. \& Jones, D.T. (2003). Lean thinking: banish waste and create wealth in your corporation. Simon \& Schuster, New York. 